\title{
Integration of grazing and herbicide application improves management of barb goatgrass and medusahead in pasture and rangelands
}

\author{
The combination of high-intensity, short-duration grazing with precisely timed applications of \\ glyphosate improves management of invasive annual grasses.
}

by Travis M. Bean, Josh S. Davy, Guy B. Kyser and Elise S. Gornish

Online: https://doi.org/10.3733/ca.2021a0011

$\mathrm{T}$ he rapid spread of invasive annual grasses across noncrop and rangeland areas causes extensive economic and ecological damage across California and other western states. Dense infestations of weedy grasses can increase fire frequency and magnitude (D'Antonio and Vitousek 1992; Lambert et al. 2010a; Lambert et al. 2010b), modify virus incidence in native bunchgrasses (Malmstrom et al. 2005), impact soil microbial communities and nutrient cycling (Batten et al. 2006; Drenovsky and Batten 2007; Gornish et al. 2020), reduce native plant diversity (DiTomaso 2000; Haferkamp et al. 2001; Parmenter and MacMahon 1983) and reduce livestock carrying capacity (Hironaka 1961; Jacobsen 1929). In western habitats with Mediterranean climates, two invasive annual Eurasian grasses of particular concern are barb goatgrass (Aegilops triuncialis L.) and medusahead (Elymus caput-medusae L., syn. Taeniatherum caput-medusae [L.] Nevski). Barb goatgrass is listed as a noxious weed by California and Oregon, and is considered an invasive pest in Nevada and several New England states. Medusahead is a statelisted noxious weed in California, Colorado, Nevada, Oregon and Utah. Although research on medusahead has been more extensive than research on barb goatgrass, it remains one of the most problematic grasses in the western United States (James et al. 2015).

\section{Abstract}

The invasive annual grasses barb goatgrass (Aegilops triuncialis L.) and medusahead (Elymus caput-medusae L.) are widespread in western states and present management challenges on grasslands. To develop an integrated management strategy for these species, we treated sites in five pastures in Mendocino County, comparing combinations of intensive sheep grazing, glyphosate herbicide (low and high), and application timings (tillering, boot and heading stage). We found that grazing alone reduced barb goatgrass spikelet densities by $68 \%$ and the number of seeds per spikelet by $35 \%$. Both rates of glyphosate application without grazing had similar effects on seed production. High and low glyphosate application at tillering resulted in almost complete control of both target species. Boot- and heading-stage applications reduced barb goatgrass density by $39 \%$ and $32 \%$, respectively. Application at the boot stage also resulted in an $82 \%$ reduction in number of seeds per barb goatgrass spikelet. Our results suggest that intensive grazing may be a useful management strategy to reduce barb goatgrass and medusahead spikelet densities and barb goatgrass seed numbers, especially when integrated with a boot- or heading-stage glyphosate application.

Barb goatgrass and medusahead are challanging invasive grasses to manage. However, new research suggests that an integrated pest management (IPM) approach using low rate herbicide application early in the plants' growth and grazing can be very effective for control. 


\section{Failure of nonintegrated approaches}

Both barb goatgrass and medusahead were introduced to the United States in the late 19th to early 20th centuries, and both have increased their ranges while responding poorly to nonintegrated management approaches (Peters 1994), especially over the long term (James et al. 2015). Both species typically invade areas dominated by functionally similar annual grasses, causing strong negative effects on the abundance of the similar species (Case et al. 2016).

Until recently, most research on controlling invasive annual grasses has focused on a single type of management (biological, chemical, cultural or mechanical) and has not included the effects of treatment timing. For example, prescribed burning can control barb goatgrass (DiTomaso et al. 2006) but, if burning is conducted too early in the plant's life cycle, temperatures or exposure time may not be sufficient to sterilize seed. If conducted too late, prescribed burning makes the seed less susceptible to injury (Sweet et al. 2008). High stocking rates of sheep at the onset of heading can reduce medusahead

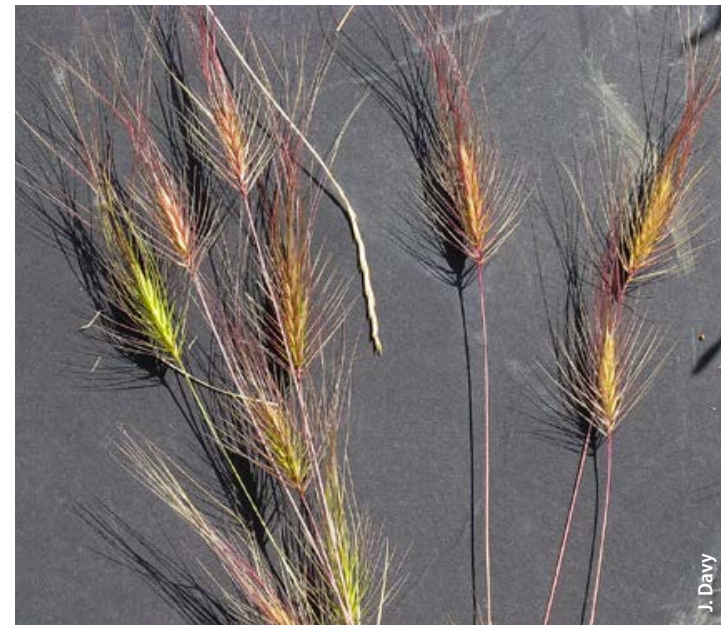

Medusahead.

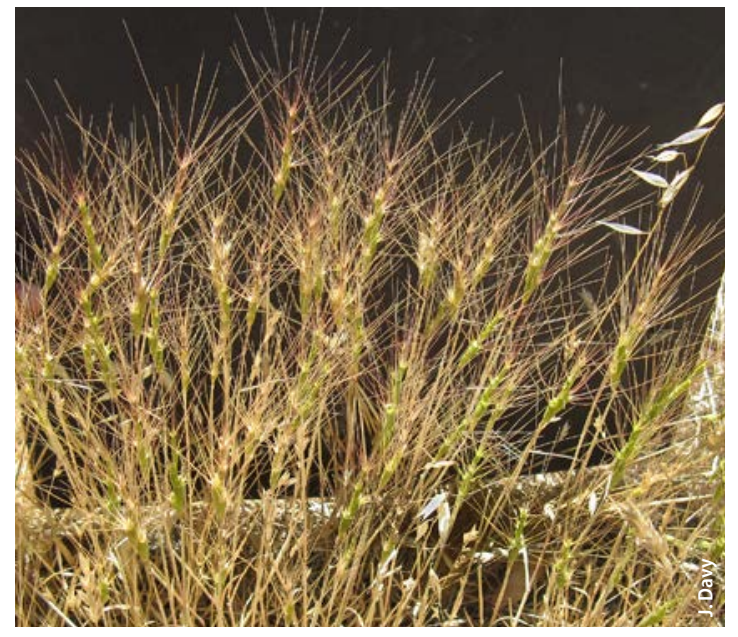

Barb goatgrass. the life cycle of a weed can directly and indirectly affect the way the plant responds to a control effort at another point in its life cycle (Blumenthal et al. 2003; Melander 1998). Clearly, a better understanding of how combined control approaches interact with phenology and treatment timing would facilitate an improved strategy for barb goatgrass and medusahead management.

\section{Integrating management approaches}

The main objective of this research was to compare the effectiveness of different application timings (at different developmental stages) using label- and reduced-rate glyphosate applications in combination with targeted grazing in reducing barb goatgrass and medusahead spikelet density and seed production. We hoped also to refine the herbicide application timing to allow use of a reduced rate. We looked at seed characteristics rather than cover because these species, like other invasive annuals, tend to dominate California landscapes in large part due to their copious seed production - not their enhanced competitive abilities (Seabloom et al. 2003).

We utilized a replicated field experiment on active rangeland with herbicide applications made at conspicuous target plant developmental stages: tillering (when side shoots are produced), boot (when inflorescence develops within the shoot) and heading (when inflorescence emerges from the shoot). We paid particular attention to the relevance and ease of use of the treatment procedures for land managers. To our knowledge, this is the first study to combine high-intensity, short-duration grazing of barb goatgrass and medusahead with precisely timed applications of different amounts of glyphosate, with a focus on reduction in seed production.

\section{Establishing experimental sites}

In fall 2015, we established plots in five pastures (table 1) at the University of California Hopland Research and Extension Center (HREC; headquarters

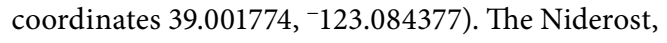
Little Buck and James pastures are productive lowlands adjacent to seasonal flow, while the Foster and South pastures are dry and open with some serpentine soils.

The HREC comprises nearly 5,400 acres (2,185 hectares [ha]) of grassland, oak woodland and irrigated pasture in the interior Coast Ranges of California. The climate at HREC is Mediterranean with hot, dry summers and mild, rainy winters. Annual precipitation averages around 40 inches $(102 \mathrm{~cm})$, with $75 \%$ of the precipitation received from November through February. Mean average temperature from July through September is $70^{\circ} \mathrm{F}$ $\left(21^{\circ} \mathrm{C}\right)$, and the mean maximum is $92^{\circ} \mathrm{F}\left(33^{\circ} \mathrm{C}\right)$. July is generally the hottest month, with daily maximum 
TABLE 1. Site locations and characteristics

\begin{tabular}{|l|l|c|l|}
\hline Site & Coordinates & Elevation $(\mathrm{m})$ & Soil \\
\hline Niderost & $38.987^{\circ} \mathrm{N}, 123.090^{\circ} \mathrm{W}$ & $175-185$ & $\begin{array}{l}\text { Yorkville-Squawrock-Witherell complex (loam, sandy } \\
\text { loam and cobbly loam) }\end{array}$ \\
\hline Little Buck & $38.995^{\circ} \mathrm{N}, 123.068^{\circ} \mathrm{W}$ & $280-290$ & Bearwallow-Hellman loam \\
\hline James & $39.031^{\circ} \mathrm{N}, 123.095^{\circ} \mathrm{W}$ & 465 & Talmage gravelly sandy loam \\
\hline Foster & $39.005^{\circ} \mathrm{N}, 123.101^{\circ} \mathrm{W}$ & $265-275$ & Henneke-Montara complex (loam and gravelly clay loam) \\
\hline South pasture & $38.985^{\circ} \mathrm{N}, 123.066^{\circ} \mathrm{W}$ & $250-270$ & Henneke-Montara complex (loam and gravelly clay loam) \\
\hline
\end{tabular}

sometimes reaching $110^{\circ} \mathrm{F}\left(43^{\circ} \mathrm{C}\right)$. Temperatures drop to a mean of $44^{\circ} \mathrm{F}$ to $47^{\circ} \mathrm{F}\left(7^{\circ} \mathrm{C}\right.$ to $\left.8^{\circ} \mathrm{C}\right)$ from December through February. The grasslands at HREC are generally on moderate slopes with loam to clay soils.

In each of the five pastures, or sites (Foster, James, Little Buck, Niderost and South), we established three replicated treatment blocks in random locations. Each block was 59 feet (ft) by $118 \mathrm{ft}$ (18 meters $[\mathrm{m}]$ by $36 \mathrm{~m}$ ) and utilized a split-split-plot design. A 59-ft-by-59-ft (18 $\mathrm{m}$ by $18 \mathrm{~m}$ ) fenced grazing enclosure on the center formed the main-plot treatment. Glyphosate rate (split-plot treatments) and application timing (split-split-plot treatments) were established both inside and outside the grazing enclosure (fig. 1). Grazing treatments were applied in a standardized manner (spatially) across sites and blocks - not randomly - due to management constraints at the site.

\section{Herbicide treatments}

Glyphosate (Monsanto Roundup WeatherMAX 4.5 pounds [lbs] acid equivalent [ae] per gallon $\left[\mathrm{gal}^{-1}\right.$ ] $\left[0.54 \mathrm{~kg} \mathrm{ae}^{-1}\right]$ ) was applied to split plots at two rates: a low rate of $0.35 \mathrm{lb}$ ae per acre $\left(\mathrm{ac}^{-1}\right)$ or 10 ounces (oz) product ac ${ }^{-1}\left(0.39 \mathrm{~kg}\right.$ ae ha ${ }^{-1}$ or $0.3 \mathrm{~L}$ product ha $\mathrm{h}^{-1}$ ) and a high rate (label recommended rate for similar annual grasses) of $1.12 \mathrm{lbs} \mathrm{ae} \mathrm{ac}^{-1}$ or $32 \mathrm{oz}$ product ac ${ }^{-1}\left(1.26 \mathrm{~kg}\right.$ ae ha ${ }^{-1}$ or $1.0 \mathrm{~L}$ product $\mathrm{ha}^{-1}$ ). Application timings were targeted to one of three phenological stages: tillering, boot or heading. All applications were made in a spray volume of 20 gal ac $^{-1}\left(187 \mathrm{~L} \mathrm{ha}^{-1}\right)$ using a $\mathrm{CO}_{2}$ backpack sprayer and a $10-\mathrm{ft}(3-\mathrm{m})$ boom with six TeeJet 11002AIXR nozzles on 20 -in (0.5-m) spacings.

Our categories represented continuous transitions from vegetative growth to flowering and senescence, not discrete categories, so slight differences in phenology existed among sites, as noted here. Tillering treatments were applied on March 22, 2016, when both barb goatgrass and medusahead were in a vegetative stage at all sites. This was also prior to flowering of other annual grasses. Boot-stage treatments were applied on May 9; at this time, while barb goatgrass at the Niderost, Little Buck and James sites were in the boot stage, plants at the drier Foster and South pasture sites had advanced to early heading. Other annual grasses had finished flowering and were beginning to senesce by this time. Headingstage treatments were applied on May 27. At this time, barb goatgrass was fully headed out at all sites; spikelets were still green at James, spikelet awns were starting to redden at Little Buck and Niderost and spikelets were starting to brown at Foster and South pastures. A heading-stage treatment was not applied at South pasture due to equipment problems.

\section{Sheep grazing treatments}

Based on sheep-grazing rates of 10 animal days per 1,076- $\mathrm{ft}^{2}$ plot applied to manage medusahead in DiTomaso et al. (2008), we planned a target rate of 32 sheep days in each of our 3,488- $\mathrm{ft}^{2}$ plots (32 sheep for one day or 16 sheep for two days, approximately 0.2 animal unit month $[A U M])$. Plots were grazed at the boot stage prior to the boot-stage herbicide applications. The South pasture plots were grazed April 18-21; Foster, April 21-26; Niderost, April 25-27; Little Buck, April 28-30; and James, May 3-5. Because forage was denser

FIG. 1. An example of the layout of experimental treatments in a single block.

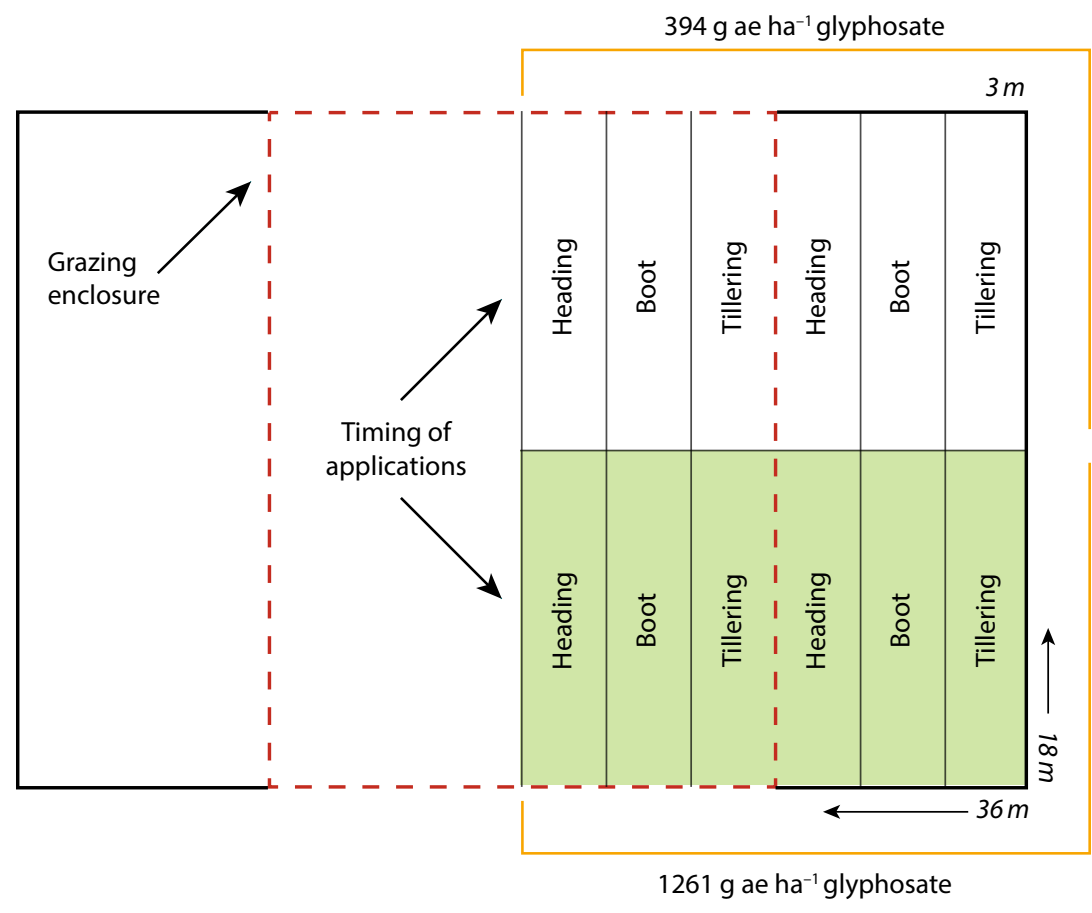




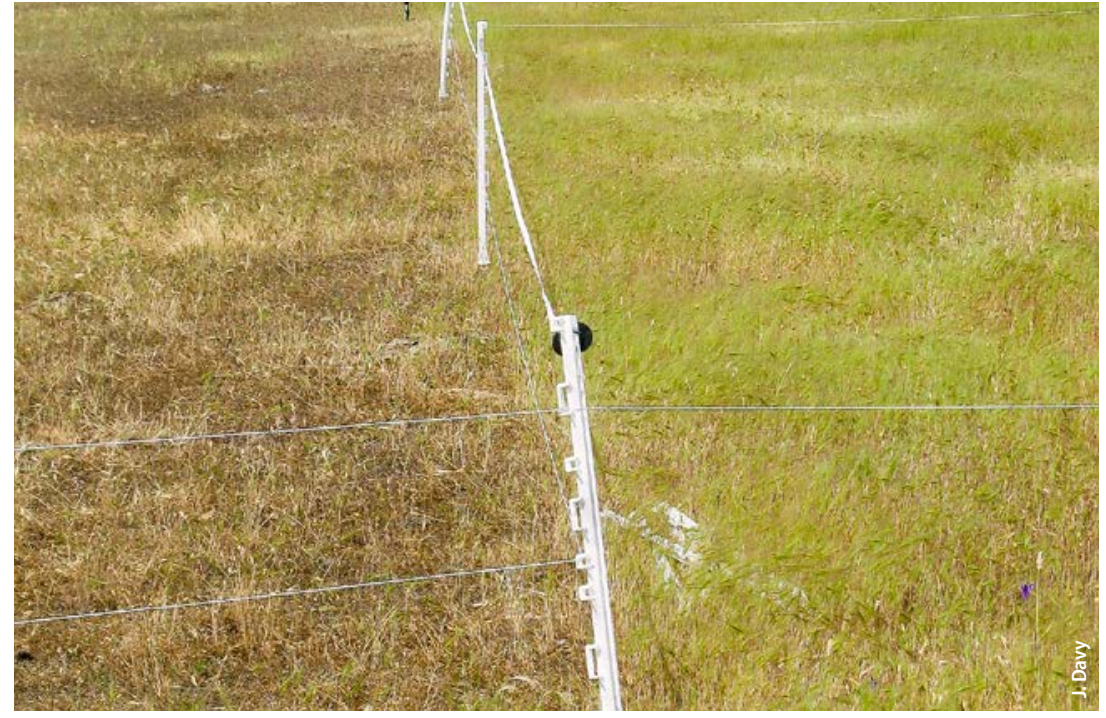

Reduced medusahead densities in grazed areas (left) compared to ungrazed areas (right).

at Niderost, Little Buck and James, sheep remained at these sites for an extra day (a total of approximately 48 sheep days) to achieve forage reduction consistent with forage reduction at South pasture and Foster.

\section{Evaluations: weed spikelet density}

Spikelet densities of both barb goatgrass and medusahead were evaluated on June 16 . Three quadrats were tossed in each glyphosate-treated split plot, and six quadrats were tossed in the larger split plots not treated with glyphosate. We used $0.5-\mathrm{m}^{2}$ quadrats to evaluate split plots with high densities of barb goatgrass and $1-\mathrm{m}^{2}$ quadrats for lower-density split plots.

\section{Evaluations: seed production}

On the same date, June 16, we also collected 10 barb goatgrass spikelets from each split plot with mature plants. Most barb goatgrass plants in grazed split plots and in split plots treated with glyphosate at tillering

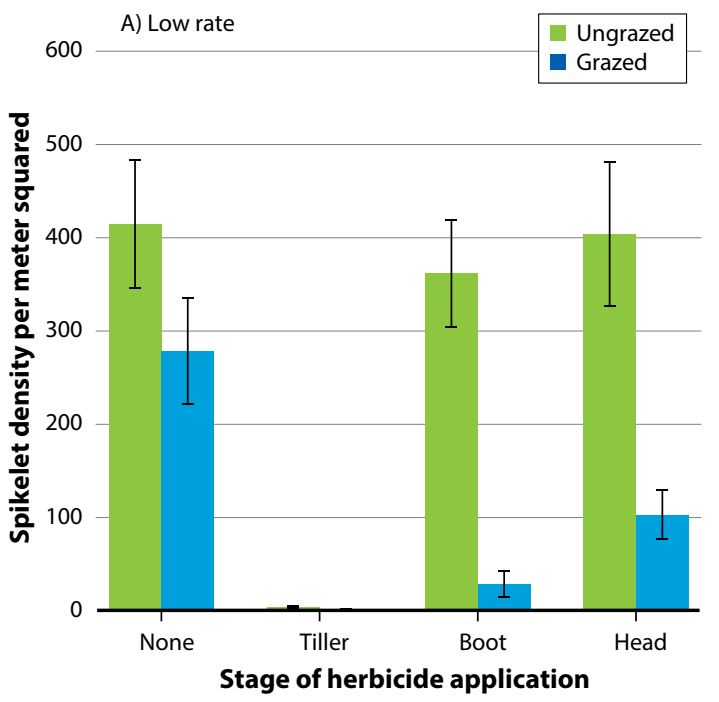

were immature, if present; therefore, we returned to collect spikelets from these plots on July 21. At this time, we found almost no barb goatgrass plants in any of the plots. Medusahead density was too low across plots to allow for spikelet collection.

\section{Assessing the models}

We used ANOVA to assess how our treatments independently and interactively affected barb goatgrass and medusahead spikelet density, modeling both species separately. Our models included the fixed factors of grazing (absent and present); glyphosate rate (none, low and high); target species stage at glyphosate application (tiller, boot and heading), and the random effect of split plot within block within site. When significant effects were found, we used Tukey HSD tests to compare treatment levels. Barb goatgrass and medusahead spikelet density values were log transformed to accommodate the assumptions of ANOVA. We used a separate ANOVA model with the same fixed and random factors to look at treatment effects on log-transformed barb goatgrass seed number. Effects of the unbalanced design (due to equipment problems at the South pasture during one treatment) on ANOVA outcomes were investigated comparing results using the grand mean and the weighted mean (Algina and Swaminathan 2011). No differences were found so data were pooled across sites. All analyses were conducted in $\mathrm{R}$ version 3.2.2 ( $\mathrm{R}$ Development Core Team 2008).

\section{Barb goatgrass spikelet density}

Grazing alone reduced overall barb goatgrass spikelet density by $68 \%(\mathrm{~F}=43.44, p<0.001)$ compared to ungrazed treatments. Glyphosate application alone reduced spikelet density by $60 \%$ overall $(\mathrm{F}=99.61$, $p<0.001$, fig. 2), and effects were similar between low- and high-rate glyphosate treatment plots. Barb

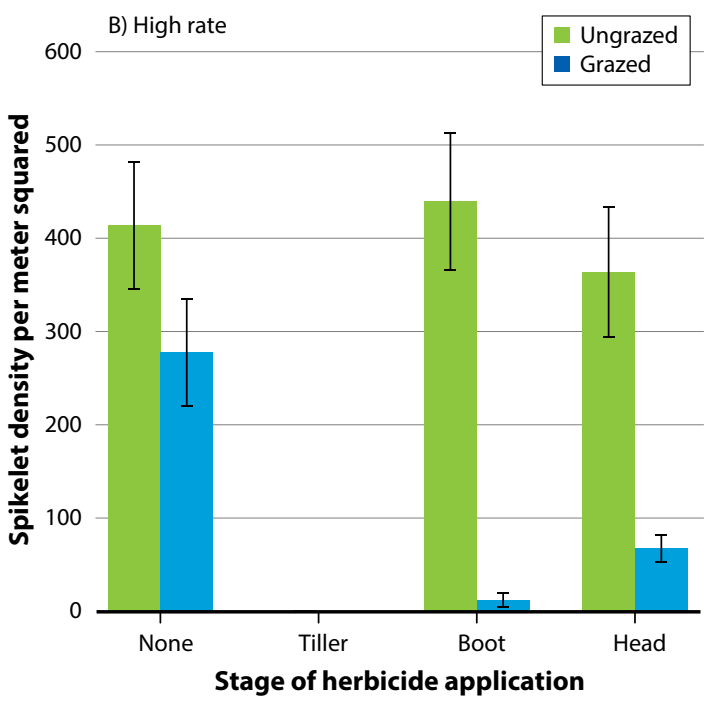

FIG. 2. Mean density \pm standard error (SE) of barb goatgrass spikelets $\left(\mathrm{m}^{-2}\right)$ for grazed and ungrazed treatments combined with low (A) and high (B) rates of glyphosate applied at tiller, boot and heading stages. 
goatgrass spikelet density was also affected by the stage at which the plants were sprayed $(\mathrm{F}=190.82, p$ $<0.001)$. Spikelet density reductions were near $100 \%$ in the tillering stage, $39 \%$ in the boot stage and $32 \%$ in the heading stage when compared to the control. We found no interactions among grazing and glyphosate rates or among glyphosate rates and stage of herbicide application.

\section{Medusahead spikelet density}

Although two of the sites were chosen based on the presence of medusahead thatch from previous years, medusahead spikelet density was very low across experimental plots during the survey period (with no differences among plots). Out of all experimental treatments, only tiller-stage glyphosate application contributed to significant differences in spikelet density ( $F=15.84, p<0.001$, fig. 3). Application of glyphosate to medusahead in the tiller stage resulted in a $99 \%$ decline in spikelet density compared to
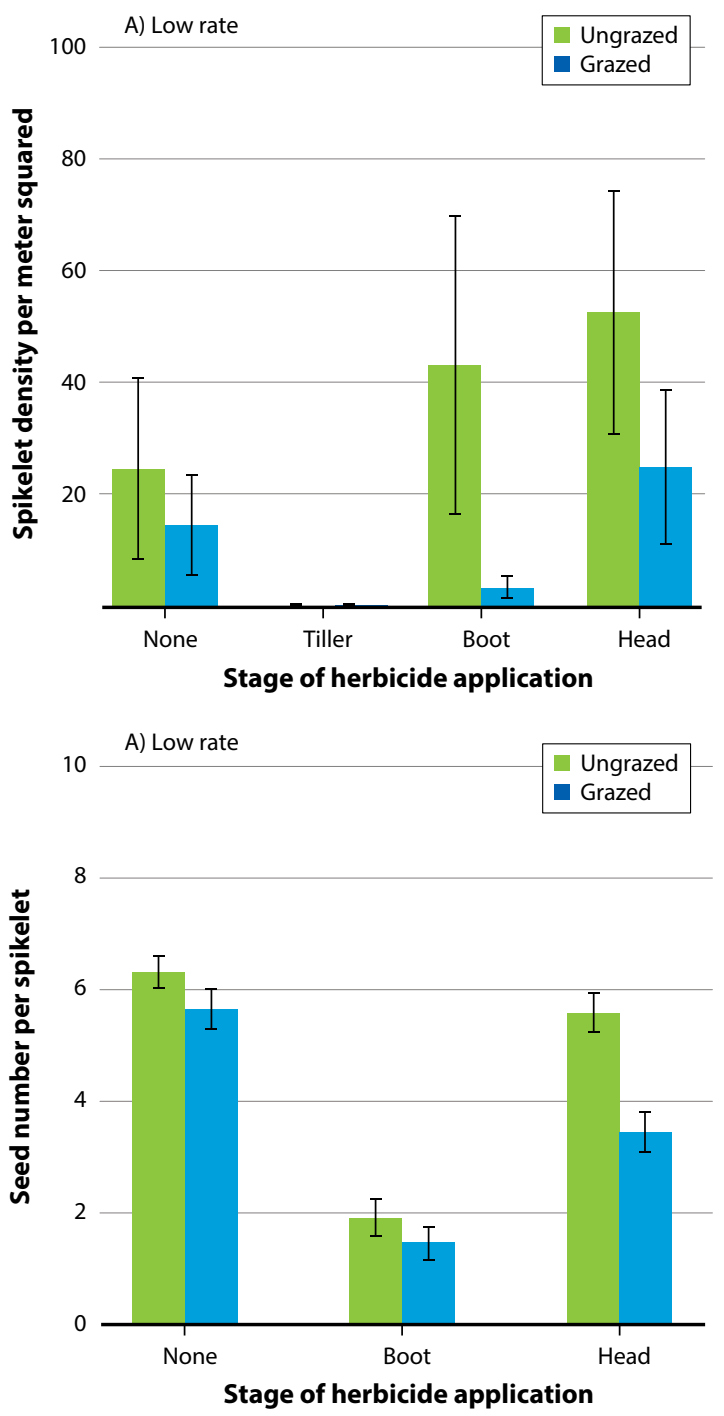

spraying at other stages. Spraying medusahead at the boot stage resulted in a $47 \%$ decline in spikelet density compared to spraying at the heading stage.

\section{Barb goatgrass seed number}

In general, barb goatgrass seed production was higher in the absence of grazing (mean $=4.2$ seeds per spikelet, $\mathrm{df}=2, \mathrm{~F}=68.68, p<0.001$; fig. 4) than it was in the presence of grazing (mean $=3.1$ seeds per spikelet). As well, barb goatgrass seed numbers showed a significant response to herbicide treatment at all stages of development. Seed numbers were higher in control plots not treated with glyphosate (mean $=5.6$ seeds per spikelet; $\mathrm{df}=2, \mathrm{~F}=93.15, p<0.001)$ compared to the plots treated with low and high rates of glyphosate (mean = 3.1 seeds per spikelet for both treatment levels, fig. $4 \mathrm{~A}$ and $4 \mathrm{~B}$ ). Seed numbers declined with the interactive effect of grazing with glyphosate rate and stage of application $(\mathrm{df}=2, \mathrm{~F}=6.91, p=0.009)$. When glyphosate was applied at the heading stage with grazing present,

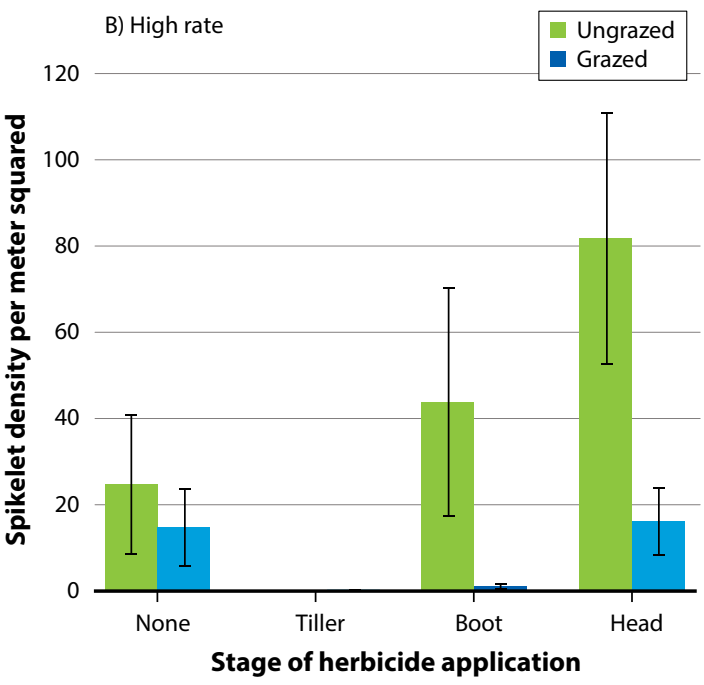

FIG. 3. Mean density \pm SE of medusahead spikelets $\left(\mathrm{m}^{-2}\right)$ for grazed and ungrazed treatments combined with low (A) and high $(B)$ rates of glyphosate applied at tiller, boot and heading stages.
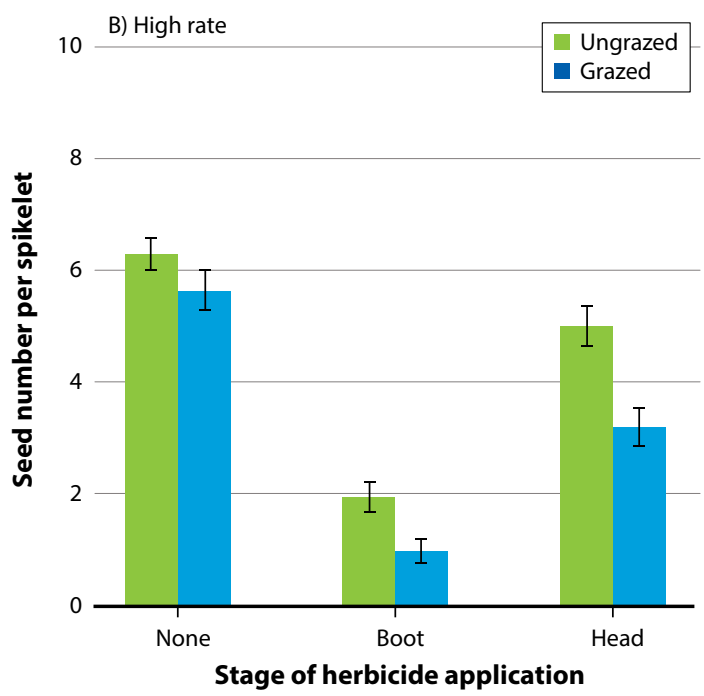

FIG. 4. Mean barb goatgrass seed number per spikelet \pm SE for grazed and ungrazed treatments combined with low $(A)$ and high (B) rates of glyphosate applied at boot and heading stages. 
Using targeted grazing in tandem with other control approaches such as low rate herbicide application can be an effective method for nonnative grass control. seed number was significantly lower compared to no grazing (fig. 4A). Seed number was also lower when high glyphosate rates combined with grazing were employed at the boot stage (fig. 4B). Seed number was lower at the boot stage (mean $=1.6$ seeds per spikelet, $\mathrm{df}=2, \mathrm{~F}=325.4, p<0.001)$ than it was at the heading stage (mean $=4.6)$. When plants were treated at tillering, barb goatgrass individuals were almost entirely absent (and seed production was effectively zero).

\section{Interpreting results}

We found that both grazing and glyphosate application are effective in reducing spikelet densities in barb goatgrass, with earlier application timings resulting in greater reductions than later application timings. Grazing was most effective when combined with later glyphosate application timings. Depending on several factors (e.g., slope and accessibility, livestock numbers available, available labor force and labor costs, fencing infrastructure, etc.), grazing treatments may be impractical on landscape scales. In such cases, intensive grazing may still be useful in targeting localized or nascent plant populations. Further, although grazing alone does not eliminate barb goatgrass or medusahead populations, reductions in spikelet density and seed number will likely translate into at least a short-term reduction in the seedbank and propagule pressure into adjacent areas (e.g., Grice 1996). This may have utility for management scenarios where chemical control options are restricted, or provide time for more intensive, integrated management efforts.

While grazing and glyphosate applications showed clear relationships in barb goatgrass, low pre-treatment density of medusahead limited our understanding of relationships among treatments and responses in this species. As with barb goatgrass, we found that earlier herbicide application timings in medusahead resulted in greater reduction of spikelet density, but we were unable to detect other differences or interactions among treatments.

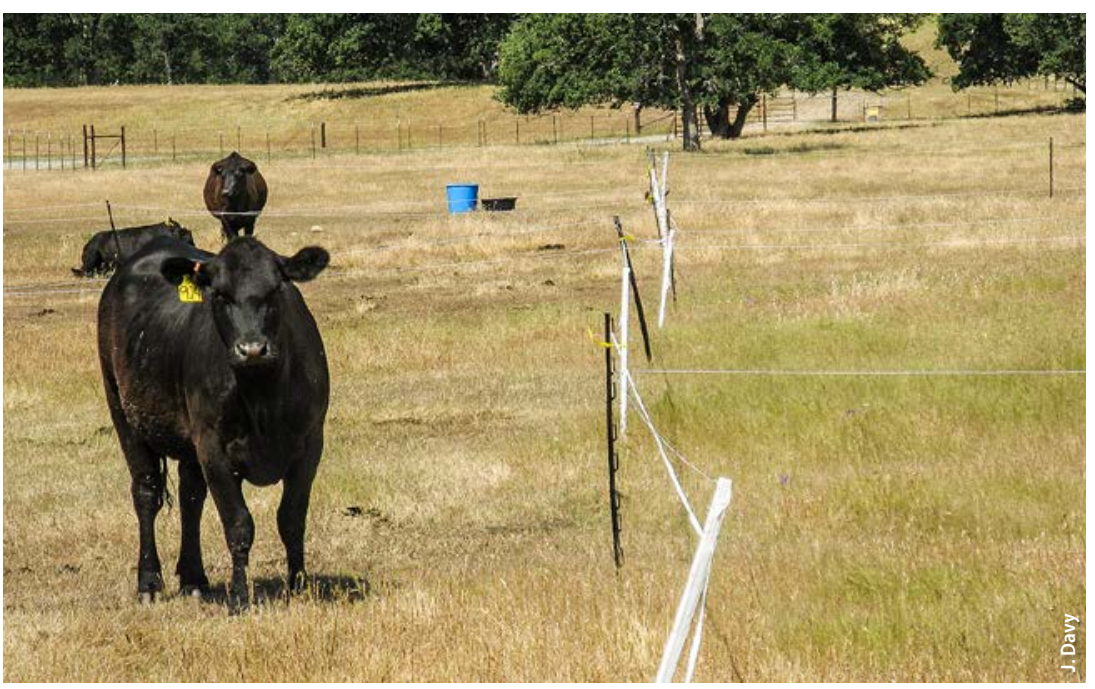

\section{Lessons for management}

We found that glyphosate application at the tillering stage resulted in nearly complete elimination of spikelet density and seed production in both species, although this timing may also incur the highest long-term damage to nontarget species (Crone et al. 2009) and limit treatment utility to specific management scenarios where active revegetation or restoration is planned or fuel breaks are required. Further, glyphosate application at tillering reduced effects of grazing on spikelet density and seed production. Early glyphosate application resulted in nearly complete control and no additional benefit was observed from grazing. Although barb goatgrass plants in the two later application stages (boot and heading) were more fully developed at the time of application, the treatments still reduced spikelet densities - but only when combined with grazing. Treatment at the boot stage may provide better spikelet reduction than at the heading stage due to growth dynamics (Evans et al. 1970), but grazing and herbicide at the heading stage still result in lower spikelet densities than they do in the control. They therefore represent a viable alternative when management actions must be delayed. The additive/synergistic effect of grazing and herbicide on spikelet production and seed number integrates multiple land uses of livestock production and conservation of natural resources compromised by invasion and supports other work that has highlighted an integrative approach (e.g., Enloe et al. 2005).

Our work also suggests the possibility of using lower herbicide rates in the management of invasive grasses. We observed no differences in medusahead or barb goatgrass spikelet densities or in barb goatgrass seed number when plants were treated with different rates (high or low) of glyphosate. Using a lower rate translates to a lower treatment cost and, though not measured in this study, may also provide increased selectivity for barb goatgrass and medusahead compared to nontarget species, especially perennials (Kyser et al. 2012; Kyser et al. 2013; Morris et al. 2016). Lowering of overall herbicide usage (and glyphosate usage in particular) is an increasingly common priority for managers and jurisdictions.

While this study demonstrates the benefit of using both grazing and reduced rate glyphosate applications for barb goatgrass control, a single year of treatment should not be considered a long-term control strategy; populations could quickly rise to pretreatment levels if grazing is discontinued (James et al. 2015). At least two years of treatment are probably necessary to achieve longer-term control for barb goatgrass (Hopkinson et al. 1999), unlike for the much shorter-lived seedbank of medusahead (Blank et al. 1996; Hulbert 1955; Sharp and Hironaka 1957). For example, DiTomaso et al. (2001) has demonstrated the need for two years of controlled burning for successful control. However, residual dry matter remaining after an initial burn may not be sufficient to carry a burn in the following year 
(DiTomaso et al. 2001). In such circumstances, glyphosate treatment as in the current study would be an ideal option to replace a second-year burn. An additional practical benefit of the glyphosate treatment is that barb goatgrass identification becomes much easier as the plants begin to mature, providing better targeting of specific infested areas. This translates to cost savings and lower impact on nontarget areas when compared to treating large areas.

To address the growing invasion of annual grasses across the western United States, managers should prioritize the use of integrated approaches. These approaches are known to be particularly effective for weed control on working landscapes (DiTomaso 2000), and they can reduce unintended negative effects on natives (Rinella et al. 2009). Our work demonstrates how considerations of phenology can be leveraged within an integrated pest management strategy for even more successful control of undesirable plant species on rangelands, a technique typically used in cropland systems (Knezevic et al. 2002). To help managers achieve their goals, future research should move beyond modeling exercises to deliver field-tested strategies for coupling integrated approaches with ecological considerations of phenology and life-cycle dynamics. CA

T.M. Bean was UC Cooperative Extension (UCCE) Specialist in Weed Science, Department of Botany and Plant Sciences, UC Riverside; J.S. Davy is UCCE Livestock, Range, and Natural Resources Advisor in Tehama, Glenn, and Colusa counties, and County Director for Tehama County; G.B. Kyser is Specialist, Department of Plant Sciences, UC Davis; E.S. Gornish is Cooperative Extension Specialist in Restoration Ecology, School of Natural Resources and Environment, University of Arizona, Tucson.

\section{References}

Aigner PA, Woerly RJ. 2011. Herbicides and mowing to control barb goatgrass (Aegilops triuncialis) and restore native plants in serpentine grasslands. Invasive Plant Sci Manag 4:448-57.

Algina J, Swaminathan H. 2011. Centering in two-level nested designs. In The Handbook of Advanced Multilevel Data Analysis. J Hox and K Roberts (eds.). New York: Routledge. p 295-312.

Batten KM, Scow KM, Davies KF, Harrison SP. 2006. Two invasive plants alter soil microbial community composition in serpentine grasslands. Biol Invasions 8:217-30.

Blank RR, Allen FL, Young JA 1996. Influence of simulated burning of soil-litter from low sagebrush, squirreltail, cheatgrass, and medusahead on water-soluble anions and cations. Int J Wildland Fire 6:137-43. Blumenthal DM, Jordan NR, Russelle MP. 2003. Soil carbon addition controls weeds and facilitates prairie restoration. Ecol appl 13:605-15.

Case EJ, Harrison S, Cornell HV. 2016. Do high-impact invaders have the strongest negative effects on abundant and functionally similar resident species? Funct Ecol 30:1447-53.

Crone EE, Marler M, Pearson DE. 2009. Non-target effects of broadleaf herbicide on a native perennial forb: a demographic framework for assessing and minimizing impacts. J Appl Ecol 46:673-82

D’Antonio CM, Vitousek PM. 1992. Biological invasions by exotic grasses, the grass/fire cycle, and global change. Annu Rev Ecol Evol Syst 23:63-87.
DiTomaso J, Heise KL, Kyser GB, et al. 2001. Carefully timed burning can control barb goatgrass. Calif Agr 55:47-53.

DiTomaso JM. 2000. Invasive weeds in rangelands: species, impacts, and management. Weed Sci 48:255-65.

DiTomaso JM, Brooks ML, Allen $E B$, et al. 2006. Control of invasive weeds with prescribed burning. Weed Technol 20:535-48.

DiTomaso JM, Kyser GB, George $M R$, et al. 2008. Control of medusahead (Taeniatherum caput-medusae) using timely sheep grazing. Invasive Plant Sci Manag 1:241-7.

Drenovsky RE, Batten KM. 2007. Invasion by Aegilops triuncialis (barb goatgrass) slows carbon and nutrient cycling in a serpentine grassland. Biol Invasions 9:107-16.

Enloe SF, DiTomaso JM, Orloff SC, Drake DJ. 2005. Perennial grass establishment integrated with clopyralid treatment for yellow starthistle management on annual range. Weed Technol 19:94-101.

Evans RA, Holbo HR, Eckert RE Jr, Young JA. 1970. Functional environment of downy brome communities in relation to weed control and revegetation. Weed Sci 18:154-62. Gornish ES, Rowe J, Franklin K, Barberán A. 2020. Buffelgras invasion and glyphosate effects on desert soil microbiome communities. Biol Invas 22:2587-97.

Grice AC. 1996. Seed production, dispersal and germination in Cryptostegia grandiflora and Ziziphus mauritiana, two invasive shrubs in tropical woodlands of northern Australia. Aust J Ecol 21:324-31.
Haferkamp MR, Grings EE Heitschmidt R, et al. 2001. Suppression of annual bromes impacts rangeland: animal responses. J Range Manag 54:663-8.

Hironaka M. 1961. The relative rate of root development of cheatgrass and medusahead. J Range Manag 14:263-7.

Hopkinson P, Fehmi J, Bartolome J. 1999. Adaptive management and fire control of barb goatgrass. Res Manage Notes 17:168-9.

Hulbert LC. 1955 Ecological studies of Bromus tectorum and other annual bromegrasses. Ecol Monogr 25:181-213.

Jacobsen W. 1929. Goatgrassa weed pest of the range. Monthly Bulletin of the Department of Agriculture, State of California 18:37-41.

James JJ, Gornish ES, DiTomaso JM, et al. 2015. Managing medusahead (Taeniatherum caput-medusae) on rangeland: a meta-analysis of control effects and assessment of stakeholder needs. Rangel Ecol Manag 68:2155-223.

Knezevic SZ, Evans SP, Blankenship EE, et al. 2002. Critical period for weed control: the concept and data anlysis. Weed Sci 50:773-86.

Kyser GB, Creech JE, Zhang

J, DiTomaso JM. 2012. Selective control of medusahead (Taeniatherum caput-medusae) in California sagebrush scrub using low rates of glyphosate. Invasive Plant Sci Manag 5:1-8.
Kyser GB, Wilson RG, Zhang J, DiTomaso JM. 2013. Herbicideassisted restoration of Great Basin sagebrush steppe infested with medusahead and downy brome. Rangel Ecol Manag 66:588-96.

Lambert AM, D'antonio CM, Dudley TL. 2010a. Invasive species and fire in California ecosystems. Fremontia 38:38.

Lambert AM, Dudley TL, Saltonstall K. 2010b. Ecology and impacts of the large-statured invasive grasses Arundo donax and Phragmites australis in North America. Invasive Plant Sci Manag 3:489-94.

Malmstrom CM, McCullough AJ, Johnson HA, et al. 2005. Invasive annual grasses indirectly increase virus incidence in California native perennial bunchgrasses. Oecologia 145:153-64.

Melander B. 1998. Interactions between soil cultivation in darkness, flaming and brush weeding when used for in-row weed control in vegetables. Biol Agric Hort 16:1-14.

Morris C, Morris LR, Surface C. 2016. Spring glyphosate application for selective control of downy brome (Bromus tectorum L.) on Great Basin rangelands. Weed Technol 30:297-302.

Parmenter RR, MacMahon JA. 1983. Factors determining the abundance and distribution of rodents in a shrub-steppe ecosystem: the role of shrubs. Oecologia 59:145-56.

Peters A. 1994. Biology and control of barb goatgrass (Aegilops triuncialis L.). Peters A, Johnson D, George M. 1996. Barb goatgrass: a threat to California rangelands. Rangelands 18:8-10.
R Development Core Team. 2008. R: A language and environment for statistical computing. Vienna, Austria: R Foundation for Statistical Computing. www.r-project.org Rinella MJ, Maxwell BD, Fay PK, et al. 2009. Control effort exacerbates invasive species problem. Ecol Appl 19:155-62.

Seabloom EW, Harpole WS, Reichman OJ, et al. 2003. Invasion, competitive dominance, and resource use by exotic and native California grassland species. Proc Nat Acad Sci 100:13384-9.

Sharp LA, Hironaka E. 1957. Viability of medusa-head (Elymus caput-medusae L.) seed collected in Idaho. J Range Manag Archives 10:123-6.

Sweet SB, Kyser GB, DiTomaso JM. 2008. Susceptibility of exotic annual grass seeds to fire. Invasive Plant Sci Manag 1:158-67.

Zhang J, Demment MW Schriefer C, et al. 2010. Control of medusahead (Taeniatherum caput-medusae) and barb goatgrass (Aegilops triuncialis) with precision defoliation. Weed Science Society of America. Denver, CO, February 7-11. 